\title{
Not Today, Old Man
}

\section{Lianda Burrows}

James Cook University, Australia

\begin{abstract}
'Not Today, Old Man' was written to the journal's call-out theme 'Tropical Gothic'. Informed by these ideas and a long tradition of women's writing from Austen to Atwood, 'Not Today, Old Man' interrogates the relationship between women and violence.

Throughout most of the twentieth century, ongoing abuse of women in a domestic environment was not considered a mitigating factor in violent action performed against the perpetrator, or indeed 'self-defence', unless taken at the time of attack. Unable to physically shield themselves from their abusers, and without a legal defence should they seek to protect themselves outside the temporal boundary of a violent attack, women were in a sense imprisoned within these relationships. In the comparatively rare instance that a woman was the perpetrator of domestic violence, 'Battered Woman Syndrome' was not available for defence in the context of Australian provocation law until the end of the twentieth century (see R v Kontinnen 1991; R v Runjanjic 1992). It is worth considering that in this same era, a man making unwelcome sexual advances to another man was considered reasonable grounds for 'self-defence' ( $R$ v Green 1997).

The landscape in 'Not Today, Old Man' is predominantly set in the tropics, but the story also alludes to the diversity of countryside and climate within Australia, both in the text itself and through allusions to authors like Gerald Murnane. The dark undertones of the piece are embedded in the depiction of these landscapes and the images they evoke. The oppressive heat, humidity, and comparatively low population of Australia's tropical regions lends itself to gothic exploration. This dark undertone was modelled on writers like David Malouf, whose fiction and poetry have been significant in endowing Australia with a sense of mythology associated with its Northern environments. As Malouf has explained, re-mythologizing the postcolonial Australian landscape gives its diverse inhabitants a renewed, 'symbolised place' to 'exist in' (cited in Mulligan \& Hill, 2001, p.110).
\end{abstract}

Keywords: landscape, Australia, gender, violence, gothic 
eTropic 18.2 (2019) 'Tropical Gothic: Literary and Creative Works' Special Issue | 94

\section{Not Today, Old Man}

\footnotetext{
7 hey drove south-west for safer water.

'Where is everyone?'

'This is everyone.'
}

So much space and so few people created a sense of unease which soaked the landscape. Waiting. But for what? It was hard to say. Rain, perhaps. Signs of life.

The two women pulled into a car-park. A single white van occupied the far corner which an overhanging tree had thrown into shade.

'This looks promising.'

Doors slammed, accoutrements gathered, staccato thongs striking the ground.

'God. It's so fucking hot.'

The creek was a thirty metre walk from the parking bay, though both women, accustomed to southern climates, complained that the distance was uncivilised.

A single man or woman capable of misery in one place is almost always capable of misery in all places. Penelope was miserable in Berlin. Miserable in London. Miserable in Scotland. Miserable in Melbourne. Miserable in Sydney. The Far North may yet prove another shade of misery, perhaps brown, or green, depending on how far out she would go, in what direction, and the time of year.

Penelope had bemoaned to a friend many years ago that she had such low self-regard that it struck her as pathetic. He paused. 'Well, you know, if you think about it, Pen, is there anything to really envy about confidence? The only confident people I know are arseholes.'

'But they're thriving. People love them.'

'Well, the world isn't very nice, it's true.'

Her mother had overheard their conversation and poked her head in to declare: 'There's bloody nothing wrong with her confidence.' Maybe she was right. Perhaps her mother meant that the voice in her head wasn't hers. She had once said to her daughter: 'Someone else put it in there. The voices in your head, the ones telling you you're no good - they're not yours.' 'It's just meaningless garbage dumped by itinerant passers-by', she'd said. If these voices belonged to someone else, then perhaps Penelope - her own voice - was confident, even steely, after all.

Later that night Penelope sat in front of her laptop, legs pulled up, sweating in the humid dark, and googled: 'How to remove voices other people have put in your head.' 
eTropic 18.2 (2019) 'Tropical Gothic: Literary and Creative Works' Special Issue | 95

At twenty-seven, Penelope had turned up on her mother's doorstep like a damaged package: 'Return to Sender'. She had come back home to the urbane, middle class luxury of being effectively rewired and reset before being sent back out into the world. Since moving North she had called her mother daily, in an attempt to repay an unbreachable debt.

Penelope was lying on her back, the pillows not so much supporting her neck but positioning it. She angled forward. Nothing was comfortable. Her bones ached. She cast her eyes at the ceiling and watched the fan spin. Sometimes, as her mother rambled and winced at her own failing bones, Penelope started to think of her more abstractly, or as a girl. Or just words assembling according to no predetermined template. She told her mum she would love it up here. Sprawled out on the beach, taut black one-piece, low slung back, fretting 'the girls' would fall out. Ashamed of the scar on her leg.

'I can see it now, mum. I've had a vision of you here! You gotta come!' And so her mother obliged.

They'd thrown towels down onto the rocks, more to shield their skin from the heat than on a quest for the illusion of comfort. Penelope had recently seen a documentary on the desert which showed kangaroos licking the thin skin over their veins, providing enough cooling to endure the sunlight. She considered trying it, assuming it wouldn't do much, but nevertheless felt drawn to test her assumption. She resolved against it, opting to swim instead. Penelope enjoined her mother.

'Come in, mum. You're ridiculous. Honestly. It's not even noticeable. I can't see it. I struggle to find it even when I look for it. It's so deep in your groin area.'

Her mother laughed and said, conspiratorially, 'That's where people are looking, darling'.

The daughter agreed. 'Oh of course they are. You're a fox. See, there! That old boy just checked you out. He's thinking "gee, I wouldn't mind letting her get a leg over."' 'Oh stop.'

'You should come swimming. It's just from an operation, the scar. That's what it looks like. It's not like people think you did that to yourself.'

'It's not that. It's ugly. It all gathers.' Penelope's mother gestured at her thigh, passing her hand over the scar before crossing her legs, relegating it again to 'sight unseen'.

Beside the creek, a man, aged sixty or so, followed his dog along an olfactory trail. Penelope and her mother dutifully aw-ed and ah-ed. He wandered over towards them. 'It's my daughter's dog', he explained.

'Cute.'

'The heat's no good for it.' 
'I can imagine.'

'\$1200 she paid. Bloody inbred. You know, when I took it to the vet they couldn't even tell me if it was a boy or a girl. Wasn't either. Inbred. Anyway, gotta take care of it until my daughter comes back from overseas. Had to get a bloody operation to turn it into a real man. There's another $\$ 700$. Fucking dog.'

Penelope looked at the dog and he wiggled his tail, or where it should be. Her mother smiled.

'It's nice of you.'

'Got no choice.'

The man continued walking along the creek, before laying down his towel.

Penelope's mother slapped at her calves.

'Ah fuck. Fucking mozzies. I read that they found a croc up here.'

'At Alligator Creek?"

'Yes. On the news.'

'I question your sources, mum. You said you read it. Anyway, I think dad's getting dementia.'

Her mother coughed on her water. 'What!? Where did that come from?'

'I've thought it for a while but haven't said anything. He... he gets lost, forgets things, repeats himself. I can't raise it with him.'

'Well, I guess he has a lot to forget.'

'Oh, come on.'

'Sorry. Ha ha! But he does! That was a good one, wasn't it?'

'Yes mum. Very funny. You haven't lost your edge.'

'But really, don't be ridiculous.'

Her mother remained silent, looking out at the water, before adding, 'I hope it isn't the case.'

When Penelope imagined her father she imagined a tall man bending down, as if to apologise. Stooped, prepared to supplicate. But the gesture was a red herring. Her father did not bend to any man or woman's will; only to God's. Even this required a painstaking, conscious application of his efforts. He would describe himself as mildmannered, in the same way that Penelope would later describe herself - which was, all in all, a lie. She pictured him in a doorway, neither coming nor going, or perhaps both. Like Pen herself, her father was always ready to leave. Poised to flee. He didn't want to be pinned down. And so, as is often the case, Pen searched for a man equally poised to leave, equally ambivalent, equally tall. There was no shortage of tall men ready to leave her. And leave they did, or she did, eventually.

'I need to find someone poised for something else. Maybe greatness.' 
Her mother's expression grew soft, almost apologetic. 'Oh Pen, it is terrible that you want someone who wants to leave.'

'That's not true. I only said that I'm drawn to men who are destined for something else - ideally greatness. Or just that they are removed, though l'd prefer it if they were removed for some noble cause, like solo sailing, or a surgeon's duty, or just any form of workaholism in general. But it can't involve another woman. I don't have the stomach for that. And they must be kind.'

Her mother nodded slowly in thought. 'Maybe you just want an equal. Someone ambitious, you know. Kind.'

'Well that's very generous, mum.'

'I worry you set yourself up for a lonely life.'

'I have great friends.'

'That's true.'

'I don't understand women that say things like "oh, all my best friends are men. I just don't get along with women." Firstly, you can't rule out $50 \%$ of people. And women are generally more empathetic. Why wouldn't you befriend them? What is this? Are you implying that women are threatened by you because you're so beautiful? Or that they're bitches? Or are you trying to tell the man you're talking to that he should have sex with you? That's a terrible, roundabout way of doing it. Men start and end with their dicks.'

'What about space travel?'

'Just a way to get the dick into space.'

Her mother laughed, shaking her head. Moments later she lurched back, flicking her towel out in front of her, gesturing at something which had fallen to the ground. 'What was that?'

'Jesus, you scared me. It's just a bean pod! I'm sorry...they look like snakes, don't they? Did it fall from the tree? It's okay, sit back down. It's just a bean pod.'

'Oh my Lord, I thought it was a snake.' Her mother, clasping her heart, sat back down. Penelope laughed. 'I told you there are dicks everywhere.'

The older man with the dog had been watching them and walked over. 'Everything ok?' They nodded silently before Penelope added, 'All good.' Standing in front of them, hand on hips, recently wet from the water, he began talking, pointing behind them, explaining this and that. The small mass in his budgie smugglers protruded at eye level, giving a heretofore unfelt force to the term. Mother and daughter averted their eyes, looking in turns at the ground and back up at the man's face.

'You only get crocs downstream. Too high up here. This was all burnt out recently. Yeah. Lived here my whole life. Divorced only two months ago.'

Unsure how to handle this change in direction, the women feigned empathy. 'Sorry to hear that.'

'Yes, sorry, that's tough.' 
'Oh no, it's for the best,' he assured them. 'I mean, I did everything. I was a good husband. She just up and left. No explanation. Nothin'. I've got a good business, builder, I think I'll move to the States, big money over there.' He came forward and turned towards Penelope. 'Too many women these days just use men, use them for money. They play nice and say all the right things and then they get married, then that's it - they never work again. Just interested in money. In whatever they can get their hands on.' Pen looked intently at the ground and turned towards her mother. Taking it upon herself to end the conversation, her mother looked at the man and smiled. 'You have a nice day then.'

'Yeah. Just watch it girls. Stay safe. You get cockatoos in those trees, knocking fruit down. Big problem.' His oration ended and he surmised he'd 'leave them to it.'

'Big problem', Penelope mimed. 'God. I was just waiting for him to ask me if it was hot enough.'

'Ridiculous. Standing there like that. His business all up in our faces.'

'I suppose we are doing the thing men fear most - that we will mock them, laugh at them behind their backs.'

'Well, they shouldn't be so absurd.'

'It must be terrible to have a daughter. You must live in fear. I'm sorry, mum.'

'What for? Don't be silly.'

'I don't think men get how afraid women are of being raped. Or killed. Walking home, in our sleep, whilst driving, at the kitchen sink.'

'No ...' Her mother's voice had trailed off.

'It's a wonder we don't explode.'

'I don't want you to worry, Penelope. It's all over. You're safe up here. I mean, as safe as can be. It's all done.'

Dusk rolled in. The branches of the fig had sprung roots, which meandered down, hung low and clung to the earth, as if to ground itself. Light from the subsiding sun still shone through the limbs, reaching towards the soil. Black metal bars; a prison illuminated. Penelope wondered whether, if left to her own devices in the desert, she too might grow wandering roots that sought water before anchoring. She stood up and stretched her arms out, briefly imagining tendrils of desperation and thirst. She gathered herself and collected her towel. To an onlooker, she had been merely stretching.

The women trundled to their car, feeling no cooler for the swim. The sun had made the steering wheel hot and sticky and Penelope's mother threw a t-shirt over it before setting off. Penelope put her earphones in and stared out the passenger-side window. Nearing home, or her new Northern home, complete with wide open spaces and heat which sucked all sense of life from them, the car slowed down at a roundabout. From 
the passenger window, Penelope saw a duck, striding along the grass towards the juncture, as though driven by some untranslatable mission. She looked briefly at her mother before turning back to the duck. Yes, it was still there. And then the white van again. How odd. She looked back at the duck. Its beak was opening and closing quacking, she imagined. To her mind, the duck became an angry protestor, marching against the relocation of a wetland, its mission transparent. 'Where is my fucking pond?' it mouthed. She was about to share the image, but then thought better of it, as she imagined her mother looking over and inadvertently veering off the road. It's not that she was a bad driver, just older, and so ... tired. In the same way that Penelope had seen old men cross a highway, boldly and without looking. They didn't fear death, certainly not at the hands of a woman. 'What are you going to do?' they demanded. 'Kill me?'

Inexplicably, Penelope felt a fault line zig-zag its way down her body. As though she was now two distinct parts of herself. One self sat silently bearing witness, and the other stood poised.

That night, the road lights repeatedly marked her entry point onto the horizon, as though she was continually arriving. One light, another kilometre, and then another light, another kilometre. Each light felt like a new beginning. By 3 am that morning, somewhere in remote New South Wales, the frost had pierced the metal hull, but that was another time and another place. She'd remembered how cold and angry she had been, desperately flooring the accelerator and releasing it, pushing down the clutch for no reason, as though the cold (or was it anger?) was some amorphous spirit, jerking out of her body haphazardly. For some reason, she had also remembered being consoled by the image of a plane crash, men and women pawing at the windows, juxtaposed with images of a baptism, a child beaming, an air of consecration and jubilation. The two images had brought her rising anger, for that's what it was, to a standstill. 'It doesn't even matter', she said aloud. 'It doesn't matter.' But the chassis from this time and place was still warm - nothing cooled; minds, hearts, nor tempers.

In the car on the way home from the creek, her mother, keeping her eyes on the road, had said: 'You really don't need to worry anymore'. Penelope said nothing. 'You're so far from everything. This is truly the middle of nowhere.'

'That old guy.'

'He's just a stupid old man. Don't worry about it. It's never them. Leave him. Everything is done. Police report has finished. You're free.'

Penelope, though a grown woman, felt like a child in her mother's presence: unburdened and unencumbered. But she wanted to correct her mother, she wanted to insist that she was never free. She saw the world now only in terms of survival. 
Scanning for threats, securing safe exits. Instead, she smiled at her mother. 'Do you know how much I love you?'

Her mother squinted into the late afternoon sun. 'Oh, stop it. No one is dying here. I love you more.'

Penelope laughed. 'More? Gosh, don't be so competitive!'

There was silence. Ignoring the joke, her mother exhaled, gathering her thoughts: 'Leave it, Pen. You're free. We don't need more trouble.'

That night, when her mother was asleep, Penelope got into the car and started driving, compelled to restore balance to a world which had consumed the best parts of her. There was nothing left. Her experiences had coloured her. She felt nothing. This was the least she could do, she thought. This is the least I can do. My innocence has come and gone. But I can protect her. She had seen the old man leave the creek. A young woman. She was sure she saw it. Maybe it was his daughter. But she didn't look like his daughter. 'Stay safe', he'd said. She saw the van on the highway pulling into a motel. Safe? She no longer presumed safety. Her own or anyone else's. She no longer experienced it - not glimpses, not even as a distraction from fear. She pulled into the motel.

Arriving back on to the doorstep that morning, neither woman had said anything. Shame had invisibly strung itself to Penelope's forehead and pulled it towards the ground. Tendrils, but not of life. Her mother, who had been joyful and relieved to see the car pull up, felt the smile struck from her face. 'What's wrong?'

'I think I hurt him.'

'What?'

Penelope lent in and whispered. 'Him.'

She pulled her daughter's shoulder forward and ushered her through the door.

'What happened?'

'I can't say, mum. I did a bad thing. Bad. I'm bad.'

'Him - where is he?'

Penelope started to cry. Quietly, but before long, hysterically, without air.

'What happened, Pen? What happened?'

Penelope tried to stop crying. She looked at the ceiling and tried to focus.

She spoke to her mother without looking down. 'I can't. I don't know what to do. I need help. I can't ask you. I don't know what to do.'

'It's okay. Whatever it is, it's okay. I'm your mother. This is my job.'

'This is not your job.'

'Yes, it is. If not this, then what? This is my job.'

'I never said anything, mum. I never said no. I thought it was my fault because I never said no. And I knew I had to say no. Because if you don't say no, there's nothing.'

'That was years ago Pen.' 
'But I did it this time. I said no. I thought he didn't hear me. I kept yelling. All this time I'd thought it was because I didn't say no, but it wasn't that. It wasn't that. It made no difference. I realised it didn't matter, all this time. None of it. Maybe he wasn't going to do anything. I don't know.' The last three words undid her.

'It's okay, it's okay. It'll be okay. I need to make some calls. I need to put the kettle on. Just stay here. Just stay here with the dog and don't go anywhere.'

Her mother walked out and felt her heart collapse inwards. She looked around, as if for her own mother, but there was no-one, nothing.

\section{References}

Mulligan, M. \& Hill, S. (2001). Ecological Pioneers: A Social History of Australian Ecological Thought and Action, Cambridge, UK: Cambridge University Press.

$R v$ Runjanjic \& R v Kontinnen (1991). 53 A Crim R 362; (1992) 56 SASR 114.

$R \vee$ Green (1997) HCA 50; (1997) 191 CLR 334; (1997) 148 ALR 659; (1997) 72 ALJR 19 (7 November 1997). 